\section{Effect of CPPU on Fruit Development of Selected Seedless and Seeded Grape Cultivars}

\author{
Thomas J. Zabadal ${ }^{1}$ and Martin J. Bukovac ${ }^{2}$ \\ Department of Horticulture, Michigan State University, East Lansing, MI 48824
}

Additional index words. berry size, table grapes, cytokinin, forchlorfenuron, Prestige

Abstract. The effects of CPPU [forchlorfenuron, N-(2-chloro-4-pyridinyl)-N-phenylurea] on berry development of Vitis labrusca and $V$. labrusca $\times V$. vinifera cultivars was evaluated under field conditions. A concentration response was initially established by spraying clusters of 'Himrod' at a mean berry diameter of about $5 \mathrm{~mm}$ with $0,5,10$, or $15 \mathrm{mg} \cdot \mathrm{L}^{-1}$ CPPU. Berry enlargement was monitored (16, 30, 44, and 59 days after treatment) during development. Cluster mass, number of berries per cluster, berry mass and firmness, and ${ }^{\circ}$ Brix were determined at harvest. Berry mass was dramatically increased ( 2.3 versus about $3.6 \mathrm{~g} / \mathrm{berry}$ ) at harvest by all concentrations of CPPU. Cluster mass and compactness were also increased and berry firmness was linearly related to CPPU concentration $\left(r^{2}=0.997\right)$. There was no significant effect on number of berries per cluster (79 to 86$)$. ${ }^{\circ} \mathrm{Brix}$, rachis necrosis at harvest, and berry abscission after 30 days of refrigerated storage $\left(1^{\circ} \mathrm{C}\right)$ were significantly reduced. Effect of time of CPPU application $\left(0,5\right.$, and $\left.10 \mathrm{mg} \cdot \mathrm{L}^{-1}\right)$ was established by treatment of clusters at mean berry diameters of about 4,5 , 7, and $9 \mathrm{~mm}$. Response was indexed by following berry enlargement at 14, 28, 42, and 56 (maturity) days after treatment. Maximum berry size for both 5 and $10 \mathrm{mg} \cdot \mathrm{L}^{-1}$ was obtained from applications at 4 to $7 \mathrm{~mm}$ berry diameter. Relative response of seedless and seeded cultivars was compared by application of CPPU at $0,5,10$, or $15 \mathrm{mg} \cdot \mathrm{L}^{-1}$ to clusters (4 to $6 \mathrm{~mm}$ berry diameter) of seedless 'Vanessa' and 'Lakemont' and seeded 'Concord' and 'Niagara'. Bioresponse was determined by a time course of berry enlargement and berry and cluster mass, number of berries per cluster, and rating cluster compactness at maturity. Except for 'Lakemont' at the $5 \mathrm{mg} \cdot \mathrm{L}^{-1}$ concentration, CPPU at all concentrations increased seedless berry diameter significantly from the first measurement at 14 through 56 days after application. Berry and cluster mass and cluster compactness were significantly increased in 'Vanessa'. In contrast, the only effect of CPPU on the two seeded cultivars was an increase in berry size in 'Concord' and an initial increase in berry size 14 days after application in 'Niagara'.

Plant growth regulators have become important tools in grape production. The use of gibberellic acid (GA) to increase berry size in Vitis vinifera table grape production began about 40 years ago (Weaver and McCune, 1961) and is now used extensively worldwide. CPPU [forchlorfenuron, N-(2-chloro-4-pyridinyl)- $\mathrm{N}^{1}$ phenylurea] is a synthetic cytokinin-like plant regulator that at low concentrations promotes grape berry set and development (Nickell, 1985). CPPU increases berry size(Diazand Maldonado, 1992; Dokoozlian et al., 1994; Dokoozlian et al., 2000; Ezzahouani, 2000; Intrieri et al., 1993; Nickell, 1985; Nickell, 1986a; Retamales et al., 1995; Reynolds et al., 1992) and set (Nickell, 1986b), delays fruit maturity (Dokoozlian et al., 1994; Dokoozlian et al., 2000; Ezzahouani, 2000; Retamales et al., 1995; Reynolds et al., 1992), reduces fruit color (Dokoozlian et al., 2000) and improves storage quality (CarvajalMillan et al., 2001). When combined with GA, CPPU acts synergistically to increase berry size (Dokoozlian et al., 1994; Ogata et al., 1988). The magnitude of the CPPU response is related to stage of berry development at time of treatment. Prebloom applications primarily increase berry set while postbloom applications affect

Received for publication 1 July 2005. Accepted for publication 3 Aug. 2005.

${ }^{1}$ Associate professor. Corresponding author; e-mail zabadal@msu.edu.

${ }^{2}$ University distinguished professor.

All studies were conducted in a vineyard at the Southwest Michigan Research and Extension Center, Benton Harbor. Vines were of moderate vigor, growing in a deep sandy loam soil, irrigated when necessary and trained to a modified-Munson system unless stated otherwise. Other cultural operations were consistent with good commercial practices.

\section{Experiment 1: Concentration response}

Forty contiguous 9-year-old 'Himrod' vines, selected for uniformity, were pruned to four 10-node fruiting canes. Flower clusters were thinned before bloom to 15 clusters/vine. One basal cluster, free of visual defects, was randomly selected on each of the four fruiting canes of each vine, and assigned to one of four treatments. Three of the designated clusters were sprayed until fully wetted with CPPU (ABG3207), Abbott Laboratories, North Chicago, Ill.) at 5,10 , or $15 \mathrm{mg} \cdot \mathrm{L}^{-1}$ using a hand-held sprayer. The cluster on the nonsprayed cane on each vine was used as a nontreated control. Each vine with the four randomly assigned treatments was considered a replication. Mean berry diameter at time of treatment was about $4 \mathrm{~mm}$.

Berry enlargement. Ten berries from each treatment on each of 10 vines $(n=100$ berries/treatment) were randomly selected and measured (smallest diameter) at 14, 28, 42, and $56 \mathrm{~d}$ after treatment.

Cluster analysis at maturity. Cluster mass and compactness, number of berries per cluster, berry mass, firmness and ${ }^{\circ}$ Brix were determined at fruit maturity on the treated clusters used for berry enlargementmeasurements plus designated clusters on an additional 15 vines ( 25 replications total). Mean berry mass was estimated by dividing number of berries per cluster into cluster mass. Brix was determined on juice extracted from about 50 sound berries per treatment. Cluster compactness was visually rated 1 through 6 as follows: 1 = rigid, unable to move berries on cluster, 2 = some movement of berries, $3=$ able to manually separate berries from one another, 4 $=$ loose, occasional berries not touching others, 5 = uniformly loose withmany berries not touching each other, some gaps apparent in cluster, and 6 $=$ large gaps apparent in cluster.

Firmness was determined at harvest on 15 randomly selected berries from each treatment (cluster) of 10 replications $(\mathrm{n}=150)$. Berries were carefully detached by cutting the pedicels and positioned on the instrument turntable with pedicels orientated to the center. Firmness was measured with a FirmTech 2 instrument (BioWorks Inc., Stillwater, Okla.) fitted with a $15-\mathrm{mm}$ flat probe. The instrument was programmed to deliver a uniform load and record the grams necessary to deform (compress) the fruit $1 \mathrm{~mm}$.

Storage evaluation. Treated clusters from the remaining 15 replications were harvested, placed in ventilated plastic harvesting boxes and immediately transferred to refrigerated storage held at $1{ }^{\circ} \mathrm{C}$. The fruit were evaluated at 10 -d intervals over $30 \mathrm{~d}$ for berry shatter by weighing and expressing the abscised berries as a percentage of total mass of the cluster. Rachis necrosis was expressed as percentage of the total rachis length, which developed a brownish discoloration.
Experiment 2: Concentration and time of application

The plant material ('Himrod') and experimental procedures were as for the concentration study except as noted below. CPPU was applied at 0,5 , or $10 \mathrm{mg} \cdot \mathrm{L}^{-1}$ at about $4,5,7$, or $9 \mathrm{~mm}$ berry diameter. Fifteen single-vine replications, each with nine single basal cluster treatments were used. Berry diameter was measured on 10 randomly selected berries on each treatment at 14-d intervals from 35 to $77 \mathrm{~d}$ after full bloom. Data collected on berry diameter at $77 \mathrm{~d}$ after full bloom and on cluster and berry parameters at maturity were based on 12 and 11 replications, respectively, due to depredation by raccoons. 
Experiment 3: Cultivar response

The comparative effect of CPPU on seedless and seeded berry development was established using the seedless Vanessa and Lakemont and seeded Concord and Niagara cultivars. Fifteen uniform 9-year-old vines of each cultivar, of moderate vigor, were selected for treatment. Vines of 'Vanessa' and 'Lakemont' were managed and prepared for treatment as described earlier for 'Himrod'. 'Concord' and 'Niagara' vines were pruned to 44 nodes $/ \mathrm{kg}$ of fruiting canes along the cordon. Cluster thinning was not performed on 'Concord' and 'Niagara'. Fourbasal clusters were selected on each vine for uniformity of development just before bloom and assigned randomly to treatments. CPPU was sprayed to runoff as previously described on individual clusters at $0,5,10$, or $15 \mathrm{mg} \cdot \mathrm{L}^{-1}$. Each vine constituted a replication $(\mathrm{n}=15)$. Berry diameterwas measured $14,28,42$, and $56 \mathrm{~d}$ after treatment. Cluster mass and compactness were determined at the time of commercial harvest.

\section{Statistical analysis}

Analysis of variance, regression analysis and, where appropriate, mean separation by Fisher's LSD or Tukey's HSD were performed using SAS statistical software.

\section{Results}

\section{Experiment 1: Concentration response}

All CPPU concentrations significantly increased berry size at all dates of measurement over the nontreated control (Fig. 1). Berry size on clusters treated with $15 \mathrm{mg} \cdot \mathrm{L}^{-1} \mathrm{CPPU}$ was significantly greater than berries from clusters treated with 5 and $10 \mathrm{mg} \cdot \mathrm{L}^{-1}$ at all measurement dates. With one exception, $42 \mathrm{~d}$ after treatment (DAT), there were no significant differences in berry diameter between 5 and $10 \mathrm{mg} \cdot \mathrm{L}^{-1} \mathrm{CPPU}$. Berry size was linearly related to concentration (e.g., at $57 \mathrm{~d}, \mathrm{Y}=14.94=0.242 \mathrm{x}$ ) at each measurement date with $r^{2}$ values of $0.585,0.647$, 0.711 , and 0.646 for $14,28,42$, and $57 \mathrm{~d}$ after treatment, respectively, all significant at $P=$ 0.001 (data not presented).

Berry diameter and mass at maturity were significantly greater for all CPPU concentrations than the controls (Table 1). Response at $15 \mathrm{mg} \cdot \mathrm{L}^{-1}$ was significantly greater than at 5 $\mathrm{mg} \cdot \mathrm{L}^{-1}$ for berry diameter and 5 and $10 \mathrm{mg} \cdot \mathrm{L}^{-1}$ for berry mass. Fruit set, measured by number of berries per cluster, was not affected. Brix was depressed ( $4 \%$ to $10 \%$ ) at all CPPU concentrations. Cluster mass was increased markedly (64\% to $76 \%$ ) at all CPPU concentrations, but there was no difference among concentrations. Cluster compactness was also increased significantly at all CPPU concentrations.

Berry shatter and rachis necrosis were reduced by CPPU during cold storage (Table 2). The effect on berry shatter was significant only at the 10-d measurement, but rachis necrosis was dramatically reduced for $30 \mathrm{~d}$.

Increasing CPPU concentration (0 to 15 $\mathrm{mg} \cdot \mathrm{L}^{-1}$ ) resulted in a linear increase (e.g., $\left.\mathrm{Y}=191.02+0.928 \mathrm{x}, r^{2}=0.918^{* * *}\right)$ in berry firmness (Fig. 2). The $r^{2}$ for firmness over the CPPU concentrations of 5,10 , and $15 \mathrm{mg} \cdot \mathrm{L}^{-1}$ was 0.997 .
Experiment 2: Concentration and time of application

Factorial analysis of the effect of CPPU concentration, applied at varying stages of early berry development, on time-course of 'Himrod' berry enlargement revealed a significant interaction. All CPPU concentrations applied at 4, 5, 7, and $9 \mathrm{~mm}$ berry diameter increased berry size significantly during the course of berry development (Table 3 ). With one exception ( $9 \mathrm{~mm}, 63 \mathrm{~d}$ after full bloom), there was no significant difference between

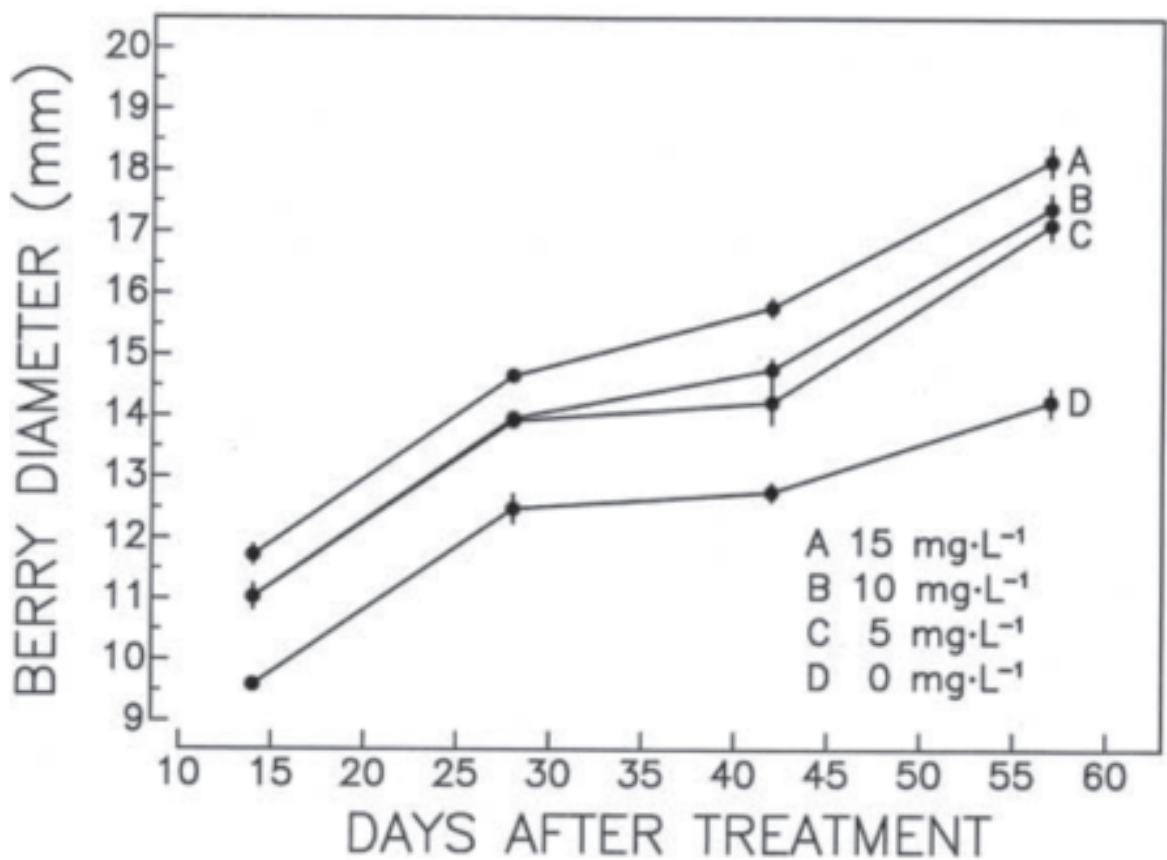

Fig. 1. Concentration effect of CPPU, applied at about $4 \mathrm{~mm}$ berry diameter, on time course of berry enlargement in 'Himrod' grape. Each data point equals a mean $(\mathrm{n}=100) \pm \mathrm{SE}$.

Table 1. Effects of CPPU concentration on berry and cluster characteristics of 'Himrod' grapes at maturity.

\begin{tabular}{|c|c|c|c|c|c|c|}
\hline \multirow{2}{*}{$\begin{array}{l}\text { CPPU } \\
\text { conch } \\
\left(\mathrm{mg} \cdot \mathrm{L}^{-1}\right)^{\mathrm{y}}\end{array}$} & \multicolumn{3}{|c|}{ Berry } & \multicolumn{3}{|c|}{ Cluster } \\
\hline & $\begin{array}{l}\text { Diam } \\
(\mathrm{mm})\end{array}$ & $\begin{array}{l}\text { Mass } \\
(\mathrm{g})\end{array}$ & $\begin{array}{l}\text { No./ } \\
\text { cluster }\end{array}$ & ${ }^{\circ}$ Brix & $\begin{array}{c}\text { Mass } \\
(\mathrm{g})\end{array}$ & $\begin{array}{c}\text { Compactness } \\
\text { (rating) }\end{array}$ \\
\hline 0 & $14.2 \mathrm{a}^{\mathrm{x}}$ & $2.28 \mathrm{a}$ & $79 a$ & $18.1 \mathrm{a}$ & $180 \mathrm{a}$ & $5.3 \mathrm{a}$ \\
\hline 5 & $17.2 \mathrm{~b}$ & $3.43 \mathrm{~b}$ & $86 a$ & $17.3 \mathrm{~b}$ & $296 \mathrm{~b}$ & $4.6 \mathrm{~b}$ \\
\hline 10 & $17.4 \mathrm{bc}$ & $3.48 \mathrm{~b}$ & $86 \mathrm{a}$ & $17.0 \mathrm{~b}$ & $299 \mathrm{~b}$ & $4.4 \mathrm{~b}$ \\
\hline 15 & $18.2 \mathrm{c}$ & $3.83 \mathrm{c}$ & $81 \mathrm{a}$ & $16.3 \mathrm{c}$ & $317 \mathrm{~b}$ & $4.4 \mathrm{~b}$ \\
\hline $\mathrm{F}$ value & $51.30^{* * * *}$ & $76.75^{* * * *}$ & $0.22^{\mathrm{NS}}$ & $19.56^{* * *}$ & $7.38^{* * *}$ & $4.90^{* *}$ \\
\hline
\end{tabular}

${ }^{\mathrm{z}}$ See text for description of rating.

${ }^{y}$ High volume spray directed at clusters at mean berry diameter of about $4 \mathrm{~mm}$.

${ }^{x}$ Means within columns followed by the same letter are not different at $P<0.05$ according to Fischer's test for least significant difference.

NS,****** Nonsignificant or significant at $P<0.01$ or 0.001 , respectively.

Table 2. Effect of CPPU on 'Himrod' berry shatter and rachis necrosis during cold storage at $1^{\circ} \mathrm{C}$ for 30 $\mathrm{d}$

\begin{tabular}{lllccc}
\hline CPPU & \multicolumn{4}{c}{ Berry shatter $(\%)^{\mathrm{z}}$} & \multicolumn{2}{c}{ Rachis necrosis $(\%)^{\mathrm{y}}$} \\
\cline { 2 - 6 } $\begin{array}{l}\text { concn } \\
\left(\mathrm{mg} \cdot \mathrm{L}^{-1}\right)\end{array}$ & 10 & 20 & Storage period $(\mathrm{d})$ & 20 & 30 \\
\cline { 2 - 6 } & $4 \mathrm{a}^{\mathrm{x}}$ & $8 \mathrm{a}$ & $10 \mathrm{a}$ & $33 \mathrm{a}$ & $44 \mathrm{a}$ \\
5 & $0 \mathrm{~b}$ & $0 \mathrm{~b}$ & $3 \mathrm{~b}$ & $14 \mathrm{~b}$ & $23 \mathrm{~b}$ \\
10 & $1 \mathrm{~b}$ & $3 \mathrm{ab}$ & $3 \mathrm{~b}$ & $7 \mathrm{~b}$ & $12 \mathrm{~b}$ \\
15 & $1 \mathrm{~b}$ & $3 \mathrm{ab}$ & $3 \mathrm{~b}$ & $7 \mathrm{~b}$ & $13 \mathrm{~b}$ \\
F value & $3.90^{*}$ & $2.69^{\mathrm{NS}}$ & $2.63^{\mathrm{NS}}$ & $10.86^{* * *}$ & $8.42^{* * * *}$ \\
\hline
\end{tabular}

${ }^{2}$ Data as a percent of the total mass of berries that abscised from the cluster.

y $D$ ata as a percent of the total length of the rachis that discolored.

'Means within columns followed by the same letter are not different at $P<0.05$ according to Fischer's Test for least significant difference.

NS,*,"*** Nonsignificant or significant at $P<0.05,0.001$, respectively. 
did not significantly increase berry mass. Berry number per cluster was significantly less, with one exception, when applied at 5 and $7 \mathrm{~mm}$ berry diameter compared to control and CPPU application at 4 or $9 \mathrm{~mm}$ berry diameter. The effect on cluster mass was similar to that on berry weight. There was no significant effect on cluster compactness.

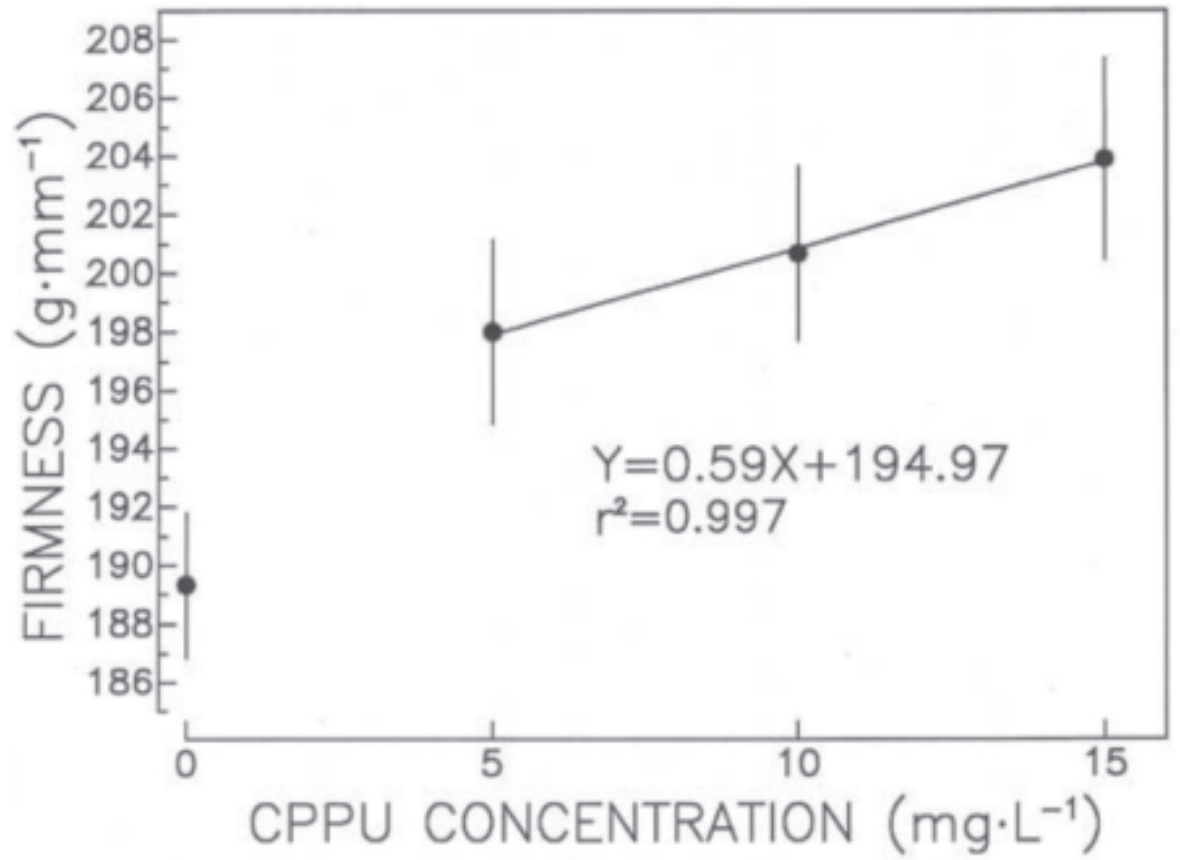

Fig. 2. Relationship between CPPU concentration and 'Himrod' berry firmness at maturity. CPPU applied at about $4 \mathrm{~mm}$ berry diameter.

Table 3. Effect of CPPU applied as a high volume spray at mean berry diameters of 4, 5, 7, and $9 \mathrm{~mm}$ on 'Himrod' berry enlargement.

\begin{tabular}{lccccc}
\hline $\begin{array}{l}\text { Berry diam } \\
\text { at time of } \\
\text { treatment } \\
(\mathrm{mm})\end{array}$ & $\begin{array}{c}\text { CPPU } \\
\text { concn } \\
\left(\mathrm{mg} \cdot \mathrm{L}^{-1}\right)\end{array}$ & \multicolumn{5}{c}{$\begin{array}{c}\text { Berry diam }(\mathrm{mm}), \\
\mathrm{d} \text { after full bloom }\end{array}$} \\
\cline { 2 - 6 } Control & 0 & 15 & 49 & 63 & 77 \\
4 & 5 & $12.7 \mathrm{c} \mathrm{ab}$ & $14.0 \mathrm{e}$ & $15.1 \mathrm{c}$ & $15.8 \mathrm{~d}$ \\
4 & 10 & $13.3 \mathrm{a}$ & $16.2 \mathrm{a}$ & $16.3 \mathrm{ab}$ & $17.3 \mathrm{abc}$ \\
5 & 5 & $12.7 \mathrm{ab}$ & $15.4 \mathrm{abc}$ & $17.0 \mathrm{a}$ & $17.8 \mathrm{ab}$ \\
5 & 10 & $12.8 \mathrm{a}$ & $15.6 \mathrm{abc}$ & $16.7 \mathrm{a}$ & $17.5 \mathrm{abc}$ \\
7 & 5 & $12.7 \mathrm{ab}$ & $15.1 \mathrm{bcd}$ & $16.3 \mathrm{ab}$ & $17.9 \mathrm{a}$ \\
7 & 10 & $12.7 \mathrm{ab}$ & $15.1 \mathrm{bcd}$ & $16.8 \mathrm{a}$ & $17.9 \mathrm{abc}$ \\
9 & 5 & $12.1 \mathrm{~b}$ & $14.5 \mathrm{de}$ & $15.7 \mathrm{bc}$ & $16.9 \mathrm{c}$ \\
9 & 10 & $12.6 \mathrm{ab}$ & $14.8 \mathrm{~cd}$ & $16.5 \mathrm{a}$ & $17.2 \mathrm{bc}$ \\
F value & & $14.7^{* * * *}$ & $14.1^{* * *}$ & $13.3^{* * * *}$ & $19.7^{* * * *}$ \\
\hline
\end{tabular}

${ }^{2}$ Means within a column followed by similar letters are not significantly different according to Tukey's HSD test at $P<0.05$.

*** Significant at $P<0.001$.

Table 4. Effect of CPPU applied at mean berry diameters of about 4, 5, 7, and $9 \mathrm{~mm}$ on berry weight and number per cluster and on cluster weight and compactness of 'Himrod' grape.

\begin{tabular}{|c|c|c|c|c|c|}
\hline \multirow{2}{*}{$\begin{array}{l}\text { Berry diam } \\
\text { at time of } \\
\text { treatment } \\
(\mathrm{mm})\end{array}$} & \multirow{2}{*}{$\begin{array}{l}\mathrm{CPPU} \\
\text { concn } \\
\left(\mathrm{mg} \cdot \mathrm{L}^{-1}\right)\end{array}$} & \multicolumn{2}{|c|}{ Berry } & \multicolumn{2}{|c|}{ Cluster } \\
\hline & & $\begin{array}{l}\text { Mass } \\
(\mathrm{g})\end{array}$ & $\begin{array}{l}\text { No./ } \\
\text { cluster }\end{array}$ & $\begin{array}{l}\text { Mass } \\
(\mathrm{g})\end{array}$ & $\begin{array}{c}\text { Compactness } \\
\text { (rating) }\end{array}$ \\
\hline Control & 0 & $3.0 \mathrm{c}^{\mathrm{y}}$ & $91 \mathrm{a}$ & $270 \mathrm{~cd}$ & 4.6 \\
\hline 4 & 5 & $3.6 \mathrm{abc}$ & 93 a & $330 \mathrm{a}$ & 4.4 \\
\hline 4 & 10 & $3.9 \mathrm{a}$ & $82 \mathrm{abc}$ & $322 \mathrm{a}$ & 4.6 \\
\hline 5 & 5 & $3.5 \mathrm{abc}$ & $70 \mathrm{c}$ & $246 \mathrm{~d}$ & 4.9 \\
\hline 5 & 10 & $3.8 \mathrm{a}$ & $71 \mathrm{c}$ & $270 \mathrm{~cd}$ & 5.0 \\
\hline 7 & 5 & $3.7 \mathrm{ab}$ & $72 \mathrm{bc}$ & $261 \mathrm{~cd}$ & 5.0 \\
\hline 7 & 10 & $3.7 \mathrm{ab}$ & $74 \mathrm{bc}$ & $273 \mathrm{~cd}$ & 4.6 \\
\hline 9 & 5 & $3.2 \mathrm{bc}$ & $91 \mathrm{a}$ & $288 \mathrm{bc}$ & 4.5 \\
\hline 9 & 10 & $3.5 \mathrm{abc}$ & $88 \mathrm{ab}$ & $304 \mathrm{ab}$ & 4.6 \\
\hline F value & & $4.88^{* * *}$ & $10.82^{* * *}$ & $18.95^{* * *}$ & $0.64^{\mathrm{NS}}$ \\
\hline
\end{tabular}

${ }^{2}$ See text for description of rating.

${ }^{y}$ Means within a column followed by similar letters are not significantly different, according to Tukey's HSD test at $P<0.05$.

${ }^{\mathrm{NS}, * * *}$ Nonsignificant or significant at $P<0.001$, respectively.
Experiment 3: Cultivar response

There was a striking difference between the response of the seedless, Vanessa and Lakemont, and seeded, Concord and Niagara, cultivars to CPPU (Table 5). CPPU (10 or $15 \mathrm{mg} \cdot \mathrm{L}^{-1}$ ) increased berry size at all measurement dates $(14,28,42$, or 56 DAT) in seedless 'Vanessa' and 'Lakemont'. At $5 \mathrm{mg} \cdot \mathrm{L}^{-1}$ berry diameter was significantly greater in 'Vanessa' on all measurement dates, and in 'Lakemont' at all dates except 14 DAT. CPPU also increased berry size in seeded 'Concord' at all dates at 10 and $15 \mathrm{mg} \cdot \mathrm{L}^{-1}$, but only at $42 \mathrm{DAT}$ at $5 \mathrm{mg} \cdot \mathrm{L}^{-1}$. In 'Niagara', the only significant berry growth response was observed at 14 DAT. The magnitude of the CPPU response was different among cultivars. The mean percentage increase in berry size over the range of CPPU concentrations $(5$, 10 , or $15 \mathrm{mg} \cdot \mathrm{L}^{-1}$ ) and measurement dates was $13 \%$ to $16 \%, 9 \%$ to $20 \%, 2 \%$ to $5 \%$, and $2 \%$ to $3 \%$ for 'Vanessa', 'Lakemont', 'Concord', and 'Niagara', respectively.

Both berry mass and number of berries per cluster in 'Vanessa' was greater at all concentrations of CPPU at harvest and this was reflected in increased cluster weight and compactness (Table 6). Interestingly, with 'Lakemont' the berry and cluster mass were increased, but berry number was not affected leading to no effect on cluster compactness. In contrast, there were no significant CPPU effects on berry mass, number of berries per cluster, cluster mass or compactness at maturity in the seeded Concord and Niagara cultivars.

\section{Discussion}

CPPU applied to clusters of seedless 'Himrod' immediately after fruit set (about 4 $\mathrm{mm}$ berry diam.) markedly increased berry development and resulted in greater cluster mass and compactness at maturity, and reduced berry shatter and rachis necrosis during refrigerated storage (Fig. 1, Tables 1 and 2). Berry size was linearly related to CPPU concentrations ( 5 to $\left.15 \mathrm{mg} \cdot \mathrm{L}^{-1}\right)$ at each measurement date during berry development. The increase in firmness was linearly related $\left(\mathrm{Y}=191.02+0.928 \mathrm{x}, r^{2}=\right.$ $0.92^{* * *}$ ) to concentration while soluble solids were inversely related and reduced by $4 \%$ to 10\% (Fig. 2, Table 1). Although this might be undesirable for fresh market, physiologically the total soluble solids per cluster was greater for CPPU-treated clusters than for the control. The increase in berry size, cluster mass, firmness, and reduction in soluble solids observed for 'Himrod', a Vitis labrusca $\times$ V. vinifera hybrid, was similar to those reported for $V$. vinifera table grape cultivars (Diaz and Maldonado, 1992; Dokoozlian, et al., 1994; Oswald, 1994). Some V. vinifera cultivars, however, (e.g., 'Thompson Seedless') may be more responsive than 'Himrod' as Dokoozlian et al., (1994) observed no further significant increase in berry size at concentrations above $5 \mathrm{mg} \cdot \mathrm{L}^{-1}$. With 'Himrod' we observed that CPPU concentrations $(5,10$ or 15 $\mathrm{mg} \cdot \mathrm{L}^{-1}$ ) significantly increased most parameters measured (Tables 1 and 2) and response to 15 $\mathrm{mg} \cdot \mathrm{L}^{-1}$ was consistently greater than $5 \mathrm{mg} \cdot \mathrm{L}^{-1}$, but not $10 \mathrm{mg} \cdot \mathrm{L}^{-1}$. The lower soluble solids and increased firmness observed in our study and 
the delayed color development observed in $V$. vinifera by Dokoozlian et al., (1994) may be a result of a general delay in berry maturity.

The effect of berry development ( 4 to $7 \mathrm{~mm}$ in diameter) at time of CPPU application on berry and cluster parameters was inconsistent (Tables 3 and 4). The response from application at $4 \mathrm{~mm}$ berry diameter was consistent with results from the previous study (Expt. 1) for berry diameter, number per cluster and mass and for cluster mass. However, response to CPPU at 5, 7 , and $9 \mathrm{~mm}$ diameter did not differ significantly from the $4 \mathrm{~mm}$ diameter treatment or tended to decrease with an increase in berry size at time of treatment. An exception was fewer berries per cluster when CPPU was applied at 5 and 7 $\mathrm{mm}$ berry diameter than at 4 or $9 \mathrm{~mm}$ diameter (about 72 vs. 90). This unexplained reduction in berry number was reflected in a cluster mass significantly lower than CPPU treatment at $4 \mathrm{~mm}$ diameter, but equal to the nontreated control (Table 4). Further, note that the mean cluster compactness for these treatments ( 5 and $7 \mathrm{~mm}$ in diameter) was not depressed relative to the control, even though the treated cluster had $21 \%$ fewer berries.

There was a striking difference in response between the seedless $V$. labrusca $\times V$. vinifera hybrids and seeded $V$. labrusca cultivars (Table 5). The seedless cultivars were very responsive to CPPU and the responses were similar to that reported for seedless $V$. vinifera (Dokoozlian et al., 1994; Oswald, 1994). These findings provide the basis of development of commercial use of CPPU for increasing the quality of some cultivars of $V$. labrusca $\times V$. vinifera hybrids comparable to $V$. vinifera, as recommended in the just approved label for use of the CPPU formulation Prestige (Valent Biosciences, 2005). In contrast, CPPU induced only a weak ('Concord') or no response ('Niagara') in the seeded $V$. labrusca cultivars. Studies are needed to clarify the basis of this differential response to CPPU.

\section{Literature Cited}

Carvajal-Millan, E., T. Carvallo, J.A. Orozco, M.A. Martinez, I. Tapia, V.M. Guerrero, A. Rascon-Chu, J. Llamas, and A.A. Cardea. 2001. Polyphenol oxidase activity, color changes, and dehydration in table grape rachis during development and storage as affected by N-(2chloro-4-pyridyl)-N-phenylurea. J. Agr. Food Chem. 49:946-951.

Diaz, D.H. and L.A. Maldonado. 1992. Forchlorfenuron effects on berry size and maturity of 'Perlette' and 'Flame' seedless grapes. Proc. Plant Growth Regulat. Soc.Amer., 19th Annu. Mtg. 19:123-128.

Dokoozlian, N.K., M.M. Moriyama, and N.C. Ebisuda. 1994. Forchlorfenthuron(CPPU) increases the berry size and delays the maturity of 'Thompson' seedless table grapes. Proc. Intl. Symp. Table Grape Prod. Anaheim, Calif. p. 63-68.

Dokoozlian, N., N. Ebisuda, S. Hammamoto, and A. Macias. 2000. Influence of CPPU on the growth and composition of several table grape cultivars. Res. Rpt. Calif. Table Grape Comm. vol. XXXI Summary \#11 (no page numbers).

Ezzahouani,A. 2000. Effects of forchlorfenuron (CPPU) and girdling on table grape cultivars 'Perlette' and 'Italia'. J. Intl. Sci. Vigne Vin. 34:57-60.

Intrieri, C., I. Filippetti, and S. Poni. 1993. Effetti del 'CPPU' sulla crescita delle bacche e sulla maturazione dell'uva in cultiuar da tavola apirene e con semi. Rivista di Frutticoltura 6:57-62.

Table 5. Effect of CPPU concentration on berry enlargement of seedless 'Vanessa' and 'Lakemont' and seeded 'Concord' and 'Niagara' grape cultivars.

\begin{tabular}{|c|c|c|c|c|c|}
\hline \multirow[b]{2}{*}{ Cultivar } & \multirow{2}{*}{$\begin{array}{c}\text { CPPU } \\
\text { concn } \\
\left(\mathrm{mg} \cdot \mathrm{L}^{-1}\right)\end{array}$} & \multicolumn{4}{|c|}{$\begin{array}{l}\text { Berry diam }(\mathrm{mm}) \text {, } \\
\text { d after treatment }\end{array}$} \\
\hline & & 14 & 28 & 42 & 56 \\
\hline \multirow[t]{4}{*}{ Vanessa } & 0 & $9.1 \mathrm{c}^{\mathrm{y}}$ & $10.1 \mathrm{c}$ & $11.9 \mathrm{~b}$ & $12.6 \mathrm{~b}$ \\
\hline & 5 & $10.2 \mathrm{~b}$ & $11.6 \mathrm{~b}$ & $13.6 \mathrm{a}$ & $14.2 \mathrm{a}$ \\
\hline & 10 & $10.3 \mathrm{ab}$ & $12.3 \mathrm{ab}$ & $13.9 \mathrm{a}$ & $14.8 \mathrm{a}$ \\
\hline & 15 & $10.8 \mathrm{a}$ & $12.7 \mathrm{a}$ & $14.3 \mathrm{a}$ & $14.6 \mathrm{a}$ \\
\hline F value & & $14.15^{* * * *}$ & $22.21^{* * * *}$ & $14.01^{* * * *}$ & $9.31^{\text {*** }}$ \\
\hline \multirow{4}{*}{ Lakemont } & 0 & $8.9 \mathrm{~b}$ & $10.9 \mathrm{c}$ & $13.5 \mathrm{c}$ & $11.2 \mathrm{c}$ \\
\hline & 5 & $9.2 \mathrm{~b}$ & $11.8 \mathrm{~b}$ & $14.3 \mathrm{~b}$ & $12.2 \mathrm{~b}$ \\
\hline & 10 & $10.4 \mathrm{a}$ & $12.7 \mathrm{a}$ & $15.3 \mathrm{a}$ & $13.3 \mathrm{a}$ \\
\hline & 15 & $10.9 \mathrm{a}$ & $12.9 \mathrm{a}$ & $15.6 \mathrm{a}$ & $13.4 \mathrm{a}$ \\
\hline F value & & $14.15^{* * * *}$ & $20.66^{* * * *}$ & $13.12^{* * * *}$ & $19.05^{* * * *}$ \\
\hline \multirow[t]{4}{*}{ Concord } & 0 & $13.4 \mathrm{~b}$ & $15.8 \mathrm{c}$ & $15.7 \mathrm{~b}$ & $16.3 \mathrm{c}$ \\
\hline & 5 & $13.4 \mathrm{~b}$ & $15.9 \mathrm{bc}$ & $16.3 \mathrm{a}$ & $16.5 \mathrm{bc}$ \\
\hline & 10 & $14.0 \mathrm{a}$ & $16.2 \mathrm{ab}$ & $16.6 \mathrm{a}$ & $16.8 \mathrm{ab}$ \\
\hline & 15 & $14.0 \mathrm{a}$ & $16.4 \mathrm{a}$ & $16.8 \mathrm{a}$ & $16.9 \mathrm{a}$ \\
\hline F value & & $4.12^{*}$ & $5.62^{* *}$ & $6.45^{* *}$ & $4.0^{* *}$ \\
\hline \multirow[t]{4}{*}{ Niagara } & 0 & $13.2 \mathrm{~b}$ & $15.3 \mathrm{a}$ & $15.7 \mathrm{a}$ & $15.7 \mathrm{~b}$ \\
\hline & 5 & $13.6 \mathrm{a}$ & $15.4 \mathrm{a}$ & $16.0 \mathrm{a}$ & $16.1 \mathrm{ab}$ \\
\hline & 10 & $13.9 \mathrm{a}$ & $15.6 \mathrm{a}$ & $16.2 \mathrm{a}$ & $16.4 \mathrm{a}$ \\
\hline & 15 & $14.0 \mathrm{a}$ & $15.5 \mathrm{a}$ & $16.1 \mathrm{a}$ & $16.3 \mathrm{a}$ \\
\hline F value & & $6.71^{* *}$ & $0.92^{\mathrm{NS}}$ & $1.23^{\mathrm{NS}}$ & $2.91^{\mathrm{NS}}$ \\
\hline
\end{tabular}

${ }^{\mathrm{z}}$ Data represent smallest berry diameter in $\mathrm{mm}$.

${ }^{y}$ Values within columns and within varieties followed by the same letter are not different at $P<0.05$ according to Fischer's Test for least significant difference.

NS, ***,**** Nonsignificant or significant at $P<0.05,0.01$, or 0.001 , respectively.

Table 6. Effect of CPPU concentration on berry and cluster characteristics of seedless 'Vanessa' and 'Lakemont' and seeded 'Concord' and 'Niagara' grape cultivars at maturity.

\begin{tabular}{|c|c|c|c|c|c|}
\hline \multirow[b]{2}{*}{ Cultivar } & \multirow{2}{*}{$\begin{array}{l}\text { CPPU } \\
\text { concn } \\
\left(\mathrm{mg} \cdot \mathrm{L}^{-1}\right)\end{array}$} & \multicolumn{2}{|c|}{ Berry } & \multicolumn{2}{|c|}{ Cluster } \\
\hline & & $\begin{array}{l}\text { Mass } \\
(\mathrm{g})\end{array}$ & $\begin{array}{l}\text { No./ } \\
\text { cluster }\end{array}$ & $\begin{array}{c}\text { Mass } \\
(\mathrm{g})\end{array}$ & $\begin{array}{c}\text { Compactness } \\
\text { (rating) }^{z}\end{array}$ \\
\hline \multirow[t]{4}{*}{ Vanessa } & 0 & $1.53 \mathrm{c}^{\mathrm{y}}$ & $84 b$ & $130 \mathrm{c}$ & $5.4 \mathrm{a}$ \\
\hline & 5 & $1.90 \mathrm{bc}$ & $132 \mathrm{a}$ & $244 b$ & $3.4 \mathrm{~b}$ \\
\hline & 10 & $2.13 \mathrm{~b}$ & $134 \mathrm{a}$ & $282 \mathrm{~b}$ & $3.1 \mathrm{~b}$ \\
\hline & 15 & $2.55 \mathrm{a}$ & $145 \mathrm{a}$ & $357 \mathrm{a}$ & $2.6 \mathrm{~b}$ \\
\hline F value & & $10.16^{* * *}$ & $6.68^{* * *}$ & $15.86^{* * * *}$ & $16.66^{* * * *}$ \\
\hline \multirow[t]{4}{*}{ Lakemont } & 0 & $2.11 \mathrm{~b}$ & $69 a$ & $152 \mathrm{~b}$ & $5.0 \mathrm{a}$ \\
\hline & 5 & $2.13 \mathrm{~b}$ & $96 a$ & $204 \mathrm{ab}$ & $4.0 \mathrm{a}$ \\
\hline & 10 & $2.97 \mathrm{ab}$ & $97 \mathrm{a}$ & $281 \mathrm{a}$ & $3.8 \mathrm{a}$ \\
\hline & 15 & $3.26 \mathrm{a}$ & $71 \mathrm{a}$ & $230 \mathrm{ab}$ & $4.0 \mathrm{a}$ \\
\hline F value & & $3.10^{\mathrm{NS}}$ & $1.12^{\mathrm{ns}}$ & $2.03^{\mathrm{NS}}$ & $0.93^{\mathrm{NS}}$ \\
\hline \multirow[t]{4}{*}{ Concord } & 0 & $3.40 \mathrm{~b}$ & $36 \mathrm{a}$ & $124 \mathrm{a}$ & $5.1 \mathrm{a}$ \\
\hline & 5 & $3.48 \mathrm{ab}$ & $34 \mathrm{a}$ & $120 \mathrm{a}$ & $5.1 \mathrm{a}$ \\
\hline & 10 & $3.71 \mathrm{ab}$ & $33 a$ & $119 a$ & $4.9 \mathrm{a}$ \\
\hline & 15 & $3.73 \mathrm{a}$ & $37 \mathrm{a}$ & $135 \mathrm{a}$ & $4.9 \mathrm{a}$ \\
\hline F value & & $2.14^{\mathrm{NS}}$ & $0.34^{\mathrm{NS}}$ & $0.32^{\mathrm{NS}}$ & $0.15^{\mathrm{NS}}$ \\
\hline \multirow[t]{4}{*}{ Niagara } & 0 & $3.83 \mathrm{a}$ & $39 a$ & $142 \mathrm{a}$ & $3.9 \mathrm{a}$ \\
\hline & 5 & $3.95 \mathrm{a}$ & $42 \mathrm{a}$ & $160 \mathrm{a}$ & $3.4 \mathrm{a}$ \\
\hline & 10 & $4.09 \mathrm{a}$ & $47 \mathrm{a}$ & $190 \mathrm{a}$ & $3.8 \mathrm{a}$ \\
\hline & 15 & $4.01 \mathrm{a}$ & $42 \mathrm{a}$ & $170 \mathrm{a}$ & $4.2 \mathrm{a}$ \\
\hline F value & & $0.39^{\mathrm{NS}}$ & $0.78^{\mathrm{NS}}$ & $1.54^{\mathrm{NS}}$ & $1.71^{\mathrm{NS}}$ \\
\hline
\end{tabular}

${ }^{\mathrm{z}}$ See text for description of ratings.

${ }^{x}$ Mean values within columns and within varieties with the same letter are not significantly different $(P<$ 0.05 ) according to Fischer's Test for least significant difference.

NS,****Nonsignificant or significant at $P<0.001$, respectively.

Nickell, L.G. 1985. New plant growth regulator increases grape size. Proc. Plant Growth Regulat. Soc. Amer. $12: 1-7$.

Nickell, L.G. 1986a. The effects of N-(2-chloro-4-pyridyl)$\mathrm{N}^{1}$-phenylurea and the 3-chloro-benzyl ester of dicamba on the growth and suger content of grapes. Acta Hort. 179:805-806.

Nickell, L.G. 1986b. Effects of N-(2-chloro-4-pyridyl)-N $\mathrm{N}^{1}$ phenylurea on grapes and other crops. Proc. Plant Growth Regulat. Soc. Amer. 13:236-241.

Ogata, R., T. Saito, and K. Oshima. 1988. Effect of Nphenyl- $\mathrm{N}^{1}$-(4-pyridyl) urea (4-PU) on fruit size; apple, japanese pear, grapevine, and kiwi-fruit. Acta Hort. 239:395-398.

Oswald, T.L. 1994. Influence of CPPU (N-(2-chloro-4-pyridyl)- $\mathrm{N}^{1}$-phenylurea) on the berry size and fruit composi- tion of several Vitis vinifera table grape cultivars. MS thesis. Dept. Plant Sci., Calif. State Univ., Fresno.

Retamales, J., F. Bangerth, T. Cooper, and R. Caliejas. 1995. Effects of CPPU and $\mathrm{GA}_{3}$ on fruit quality of 'Sultanina' table grape. Acta Hort. 188:149-157.

Reynolds, A.G., D.A. Wardle, C.Zurowski, and N.E. Looney. 1992. Phenylureas CPPU and thidiazuron affect yield components, fruit composition, and storage potential of four seedless grape selections. J. Amer. Soc. Hort. Sci. 117:85-89.

Valent Biosciences Corp. 2005. Plant growth regulator,

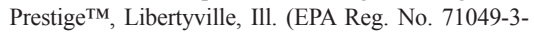
73049).

Weaver, R.J. and S.B. McCune. 1961. Effect of gibberellin on vine behavior and crop production in seeded and seedless Vitis vinifera. Hilgardia 30:425-444. 